\title{
Alveolar macrophages are the main source for tumour necrosis factor- $\alpha$ in patients with sarcoidosis
}

\author{
H. Fehrenbach*, G. Zissel ${ }^{\#}$, T. Goldmann", T. Tschernig ${ }^{+}$, E. Vollmer", R. Pabst ${ }^{+}$, J. Müller-Quernheim"
}

Alveolar macrophages are the main source for tumour necrosis factor- $\alpha$ in patients with sarcoidosis. H. Fehrenbach, G. Zissel, T. Goldmann, T. Tschernig, E. Vollmer, R. Pabst, J.Müller-Quernheim. (C) ERS Journals Ltd 2003.

ABSTRACT: Tumour necrosis factor (TNF)- $\alpha$ is known to play a major role in the formation of noncaseating granuloma, a hallmark of sarcoidosis. The main cellular source in situ is still ambiguous.

Serial sections of transbronchial biopsies from 14 patients with and 12 without sarcoidosis were studied, using immunohistochemistry (IHC), for TNF- $\alpha$, T-cells (CD3), macrophages (CD68), and epithelial cells (MNF116). TNF- $\alpha$ spontaneously released $(\mathrm{sr}-\mathrm{TNF}-\alpha)$ by freshly isolated bronchoalveolar lavage cells, isolated from the same patients and cultured without any stimulus over a 24 -h period was measured using an enzyme-linked immunosorbent assay.

IHC revealed colocalisation of TNF- $\alpha$ with CD68 cells only. Cases with TNF- $\alpha$ tissue immunoreactivity exhibited higher $\mathrm{sr}-\mathrm{TNF}-\alpha\left(1,667 \pm 504 \mathrm{pg} \cdot \mathrm{mL}^{-1}\right)$ than cases without tissue immunoreactivity $\left(211 \pm 60 \mathrm{pg} \cdot \mathrm{mL}^{-1}\right)$. In an explorative approach, a subgroup of patients could be identified and characterised by the presence of alveolar macrophage aggregates. It was found that sr-TNF- $\alpha$ was highest in this subgroup $\left(2,700 \pm 769 \mathrm{pg} \cdot \mathrm{mL}^{-1}\right)$ compared with patients with normal histology $\left(221 \pm 61 \mathrm{pg} \cdot \mathrm{mL}^{-1}\right)$ or with prominent granuloma $\left(460 \pm 137 \mathrm{pg} \cdot \mathrm{mL}^{-1}\right)$, whereas in most clinical parameters this subgroup was intermediate.

The findings from this study strongly corroborate the view that alveolar macrophages are the main cellular source for tumour necrosis factor- $\alpha$ in the initial phase of sarcoidosis. The authors suggest that in these patients, aggregates of alveolar macrophages may represent at least predecessors to granulomas if not granulomas in statu nascendi.

Eur Respir J 2003; 21: 421-428.

\author{
*Dept of Internal Medicine (Respira- \\ tory Medicine), Philipps-University, \\ Marburg, ${ }^{\#}$ Dept of Pneumology, Medi- \\ cal University Hospital, Freiburg, 'Dept \\ of Clinical and Experimental Pathology, \\ Medical Hospital, Research Centre, \\ Borstel, and Dept of Functional and \\ Applied Anatomy, Hannover Medical \\ School, Hannover, Germany.
}

Correspondence: H. Fehrenbach, Clinical Research Group "Chronic Airway Diseases", Dept. of Internal Medicine (Respiratory Medicine), PhilippsUniversity, Baldingerstrasse, D-35034 Marburg, Germany.

Fax: 4964212868987

E-mail: heinz.fehrenbach@mailer. uni-marburg.de

Keywords: Alveolar macrophages granuloma formation sarcoidosis

tumour necrosis factor

Received: September 42002

Accepted after revision: November 25 2002

This work was supported by a grant from the Deutsche Forschungsgemeinshaft (DFG, Mu692/5-6) and the Bundesministerium für Bildung und Forschung (BMBF, 01ZZ5904).
Sarcoidosisis, a systemic granulomatous disease of unknown aetiology, is characterised by its pathological hallmark, the noncaseating granuloma [1-5]. Because the lungs and thoracic lymph nodes are almost always involved, most patients report acute or insidious respiratory problems. Granuloma formation is characterised by the accumulation, proliferation and spontaneous activity of macrophages and T-lymphocytes at sites of inflammation. Once mononuclear inflammatory cells accumulate in the lung, macrophages aggregate and differentiate into epithelioid and multinucleated giant cells. $\mathrm{CD} 4^{+} \mathrm{T}$-cells are interspersed among these inflammatory cells and both $\mathrm{CD}^{+}$ and $\mathrm{CD}^{+}$lymphocytes, with a minor contribution from B-lymphocytes, form a rim around the granuloma.

Among the mediators released by bronchoalveolar lavage (BAL) cells, tumour necrosis factor (TNF)- $\alpha$ is thought to play a major role in the recruitment and maintenance of granuloma [6]. In general, immune cells, e.g. alveolar macrophages, are major sources of TNF- $\alpha$ in the lung [7]. The spontaneous release of TNF- $\alpha$ [8], interleukin (IL)-1 [9], and IL-2 [10] by activated macrophages and T-cells is considered pivotal to the formation of immune granulomas. Activated T-cells may also contribute to the release of pro-inflammatory cytokines like
TNF- $\alpha$ into the BAL fluid [11-13]. In addition, pulmonary epithelial cells, which are able to act as accessory cells in T-cell activation, and in immunoregulation cells of the lung [14] may also release TNF- $\alpha$ under certain conditions [15-17]. Furthermore, the pool of bioactive TNF- $\alpha$ is additionally regulated by the release of soluble TNF receptors [18]. Most of these data have been obtained from isolated cells or from the analysis of BAL cells and fluid. However, less is known about the situation in situ.

Therefore, in this explorative study, the authors investigated which cell type may be considered as the main cellular source for in situ TNF- $\alpha$ release in the lungs of patients with pulmonary sarcoidosis. The authors first measured the levels of TNF- $\alpha$ spontaneously released $(\operatorname{sr}-\mathrm{TNF}-\alpha)$ by freshly isolated BAL cells of sarcoidosis versus nonsarcoidosis patients by enzyme-linked immunoabsorbent assay (ELISA) as described in a previous study [8]. Levels of $\operatorname{sr}-\mathrm{TNF}-\alpha$ were then correlated with the presence of TNF- $\alpha$ immunoreactive cells in transbronchial biopsies of the same subjects. In a later stage, serial sections of these transbronchial biopsies were analysed by immunohistochemistry (IHC) for colocalisation of TNF- $\alpha$ with markers for macrophages (CD68), T-cells (CD3), and 
epithelial cells (cytokeratin: MNF116), respectively, to reveal which cell types were likely to be the main cellular source for $\mathrm{TNF}-\alpha$ in situ.

\section{Material and methods}

\section{Study design}

Freshly isolated BAL cells from 14 patients with and 12 patients without sarcoidosis were cultured without any stimuli over a period of $24 \mathrm{~h}$. Levels of sr-TNF- $\alpha$ in the supernatant were measured by ELISA [8, 19]. Serial sections of transbronchial biopsies obtained from the same patients during diagnostic bronchoscopy were analysed by standard IHC for TNF- $\alpha[20,21]$. The staining pattern was correlated with IHC patterns for markers of T-cells (CD3), macrophages (CD68), and epithelial cells (cytokeratin: MNF116). Associations of the IHC patterns with the levels of sr-TNF- $\alpha$ were tested for significance.

\section{Patient characteristics}

The diagnosis of pulmonary sarcoidosis was established in 14 individuals using defined criteria, including transbronchial biopsy [3]. For the purpose of this study, the patients were grouped as "clinically active sarcoidosis" or "clinically inactive sarcoidosis". The clinical criteria used was new or progressing pulmonary symptoms $e$.g. cough and dyspnoea, newly evolving or progressing radiographic abnormalities, and/or systemic symptoms according to the recent recommendations of the World Association of Sarcoidosis and Other Granulomatous Disorders [22]. The control group consisted of 12 patients undergoing a diagnostic bronchoscopy in the course of their clinical work-up, and were retrospectively found free of any inflammatory or malignant pulmonary disease. Only patients proven to be free of any disease, possibly confounding immunological tests, entered the control group. Functional, serological, and BAL parameters were assessed as described earlier [19]. A BAL was performed in the course of a clinically indicated bronchoscopy either for diagnosis or re-evaluation of inflammatory activity. None of the patients received antiinflammatory or steroid therapy at the time of the BAL. Table 1 shows the characteristics and demographic descriptions of the sarcoidosis patients and the control patients.

\section{Bronchoalveolar lavage and cell culture}

Bronchoscopy and BAL were performed as described previously $[8,19]$. A volume of $200-300 \mathrm{~mL}$ of sterile saline $(0.9 \%$ $\mathrm{NaCl}$ ) was instilled into a lingula or middle-lobe segment in $25 \mathrm{~mL}$ aliquots. Each aliquot was immediately aspirated. Recovery was (mean \pm SEM) $68.9 \pm 9.9 \%$ in the nonsarcoidosis group versus $61.9 \pm 11.2 \%$ (NS) in the sarcoidosis group.

Immediately after BAL, the cells were centrifuged at $500 \times g$ and washed three times with phosphate buffered saline (PBS) at $4^{\circ} \mathrm{C}$. Freshly isolated BAL immune cells were cultured, without any stimuli, at a density of $10^{6} \cdot$ cells $\cdot \mathrm{mL}^{-1}$ for a period of $24 \mathrm{~h}$ in an endotoxin-free Roswell Park Memorial Hospital (RPMI) 1640 medium (Seromed, Berlin, Germany) in a humidified $5 \% \mathrm{CO}_{2}$ atmosphere at $37^{\circ} \mathrm{C}$. The medium was supplemented with $2 \%$ human $\mathrm{AB}$ serum (Blutbank Lütjensee, Lütjensee, Germany), $2 \mathrm{mM}$ L-glutamine (GIBCO, Wiesbaden, Germany), $100 \mathrm{U} \cdot \mathrm{mL}^{-1}$ penicillin (GIBCO), and $100 \mu \mathrm{g}$ streptomycin (GIBCO). At the end of the culture period, the supernatants were harvested and stored at $-70^{\circ} \mathrm{C}$ until assayed for TNF- $\alpha$.
Table 1. - Patient characteristics

Patients

Nonsarcoidosis Sarcoidosis

\begin{tabular}{lcc}
\hline Subjects n & 12 & 14 \\
Age yrs & $44.5 \pm 11.8$ & $45.1 \pm 13.4$ \\
Female & 8 & 6 \\
Male & 4 & 8 \\
Smoker & 2 & 2 \\
Nonsmoker & 10 & 12 \\
Cell differentials & & \\
Cell number $\times 10^{6} \cdot 10^{-2} \mathrm{~mL}$ & $10.1 \pm 9.9$ & $11.2 \pm 8.4$ \\
Alveolar macrophages \% & $96.3 \pm 3.3$ & $73.1 \pm 15.5^{* * * *}$ \\
Lymphocytes \% & $4.6 \pm 7.2$ & $23.9 \pm 14.6^{* * *}$ \\
Neutrophils \% & $0.9 \pm 1.4$ & $2.4 \pm 2.9$ \\
Eosinophils \% & $0.2 \pm 0.5$ & $0.7 \pm 1.6$ \\
Lymphocyte subpopulations & & \\
CD3 \% & $40.0 \pm 56.6$ & $79.4 \pm 11.1$ \\
CD4 \% & $42.0 \pm 31.1$ & $51.0 \pm 14.2$ \\
CD8 \% & $31.5 \pm 33.9$ & $30.3 \pm 11.5$ \\
CD4/CD8 & $2.2 \pm 2.6$ & $2.1 \pm 1.4$ \\
IL-2R \% & $1.8 \pm 1.7$ & $1.5 \pm 1.2$ \\
ACE units & $47.7 \pm 21.6$ & $79.1 \pm 35.9$ \\
HLA-DR \% & $4.5 \pm 2.1$ & $11.6 \pm 4.2^{\#}$ \\
Functional characteristics & & \\
VC \% pred & $104.9 \pm 21.0$ & $85.7 \pm 20.6$ \\
TLC \% pred & $99.5 \pm 11.9$ & $87.7 \pm 17.6$ \\
FEV1/VC \% pred & $85.2 \pm 5.8$ & $78.4 \pm 19.9$ \\
DL,CO \% pred & $90.0 \pm 27.1$ & $64.8 \pm 20.8$ \\
\hline
\end{tabular}

The data are presented as mean \pm SD unless otherwise stated; IL: interleukin; ACE: angiotensin-converting enzyme; HLA: human lymphocyte antigen; VC: vital capacity; TLC: total lung capacity; FEV1: forced expiratory volume in one second; $D \mathrm{~L}, \mathrm{CO}$ : diffusion capacity for carbon monoxide. ***: $\mathrm{p}<0.001$; \#: $\mathrm{p}<0.02$.

Cell viability was determined by trypan blue exclusion and always exceeded $95 \%$ after $24 \mathrm{~h}$ of culture.

\section{Enzyme-linked immunoabsorbent assay for tumour necrosis factor $-\alpha$}

TNF- $\alpha$ was measured in cell culture supernatants using an established ELISA as described earlier [8, 19]. The antibodies to recombinant human TNF- $\alpha$ (anti-rhTNF, clone 195; which were kindly provided by E. Schlick, Knoll AG, Ludwigshafen, Germany), detect the biologically effective epitope of TNF- $\alpha$. Therefore, only biologically active TNF- $\alpha$ is measured; TNF- $\alpha$ bound to soluble receptors should not be detected. This is supported by the observation that the TNF- $\alpha$ content of the supernatants, as measured by ELISA, correlated with the bioactivity measured with the L-cell assay $\left(\mathrm{r}_{\mathrm{s}}=0.85, \mathrm{p}<0.001\right.$, $\mathrm{n}=23$, range $20-5,000 \mathrm{pg} \cdot \mathrm{mL}^{-1}$; data not shown) over a wide range of TNF- $\alpha$ concentrations released by alveolar macrophages either spontaneously or after stimulation in vitro. The TNF- $\alpha$ level of the 12 control patients was $231 \pm 76 \mathrm{pg} \cdot \mathrm{mL}^{-1}$ (range $0-746 \mathrm{pg} \cdot \mathrm{mL}^{-1}$, median $85 \mathrm{pg} \cdot \mathrm{mL}^{-1}$; fig. 1 ), which compares favourably with previously reported control levels of $220 \pm 37 \mathrm{pg} \cdot \mathrm{mL}^{-1}[19]$.

\section{Fixation and immunohistochemistry}

Transbronchial biopsies were fixed in buffered $4 \%$ formalin, and embedded in paraffin. Paraffin sections were stained according to indirect IHC as described earlier [20, 21]. After antigen retrieval (table 2), dewaxed sections were incubated 

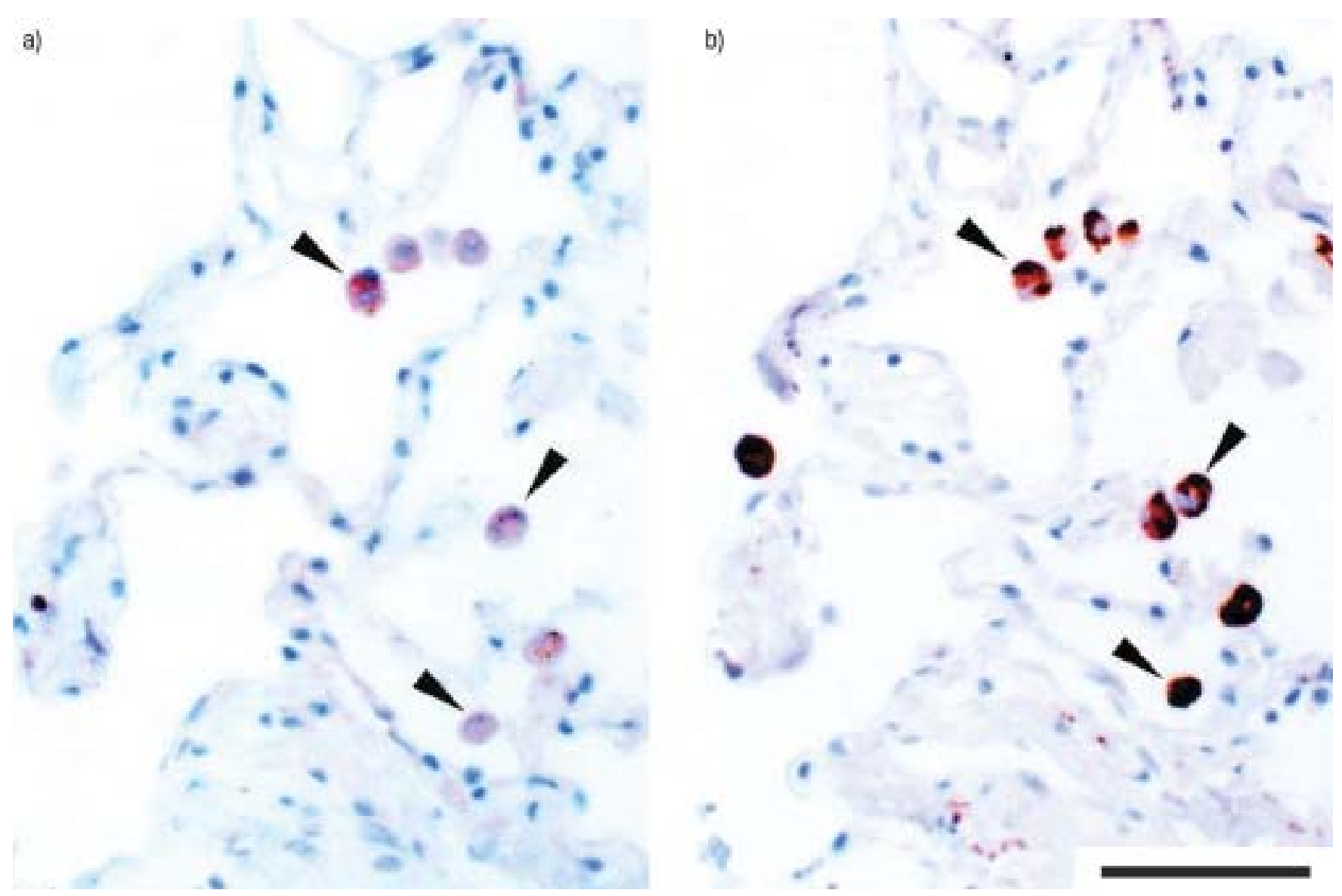

Fig. 1. - Indirect immunohistochemistry of a) tumour necrosis factor (TNF)- $\alpha$ of a transbronchial biopsy from a nonsarcoidosis patient and of an adjacent serial section stained for b) macrophage CD68 showed that only alveolar macrophages (arrowheads) exibit immunoreactivity for TNF- $\alpha$. The bronchoalveolar lavage cells spontaneously released medium levels of TNF- $\alpha\left(566 \mathrm{pg} \cdot \mathrm{mL}^{-1}\right)$ into the supernatant. Scale bar=50 $\mu \mathrm{m}$.

with hydrogen peroxide, and 50\% foetal calf serum in PBS prior to incubation with the primary antibodies used at the appropriate dilution (table 2). After washing with PBS, the primary antibody was detected by an antimouse kit according to the avidin-biotin peroxidase complex technique (Vectastain Elite kit; Vector Laboratories, Burlinghame, CA, USA). Finally, sections were counterstained with haematoxylin.

Stainings of serial sections of transbronchial biopsies were analysed for the following: 1) the presence or absence of cells exhibiting immunoreactivity for TNF- $\alpha$; 2) the presence or absence of CD3 immunoreactive cells; 3) negative, moderate or strong immunoreactivity for CD68; 4) moderate or strong immunoreactivity for cytokeratins (MNF 116); and 5) the presence/absence of normal histology, granulomas and aggregates of alveolar macrophages, respectively. For each staining, the levels of sr-TNF- $\alpha$ were plotted according to the respective histological or IHC category, which were then tested for significant differences.

Control stainings included the omission of primary antibodies and the use of irrelevant monoclonal antibodies. There was no immunoreactive labelling in control experiments (not shown).

\section{Statistics}

Data are given as mean \pm SEM unless otherwise stated. Differences in clinical parameters between nonsarcoidosis and sarcoidosis patients were tested for significance by the Mann-Whitney U-test. To test for significant differences between histological categories one-way analysis of variance (ANOVA) or Kruskal-Wallis ANOVA on ranks were used.

Table 2.-Details of immunohistochemical analysis

\begin{tabular}{|c|c|c|c|c|c|}
\hline Marker & Main specificity & Type of antibody & Origin & Dilution & Antigen retrieval \\
\hline TNF- $\alpha$ & To be analysed & $\begin{array}{l}\text { Affinity-purified mouse antihuman } \\
\text { monoclonal } \operatorname{IgG}_{1}(\mathrm{sc}-7317)\end{array}$ & Santa Cruz Biotechnology & $1: 3$ & Microwave \\
\hline CD3 & T-cells & $\begin{array}{c}\text { Mouse antihuman monoclonal antibody } \\
\text { (clone PS1) }\end{array}$ & Ventana & Prediluted solution & Microwave \\
\hline CD68 & Macrophages & $\begin{array}{l}\text { Mouse antihuman monoclonal } \mathrm{IgG}_{3} \\
\text { (clone PG-M1) }\end{array}$ & Dako & $1: 200$ & Microwave \\
\hline Cytokeratin & Epithelial cells & $\begin{array}{l}\text { Mouse antihuman monoclonal antibody } \\
\text { (clone MNF116) }\end{array}$ & Dako & $1: 150$ & Pronase \\
\hline
\end{tabular}

TNF: tumour necrosis factor; Ig: immunoglobulin. 

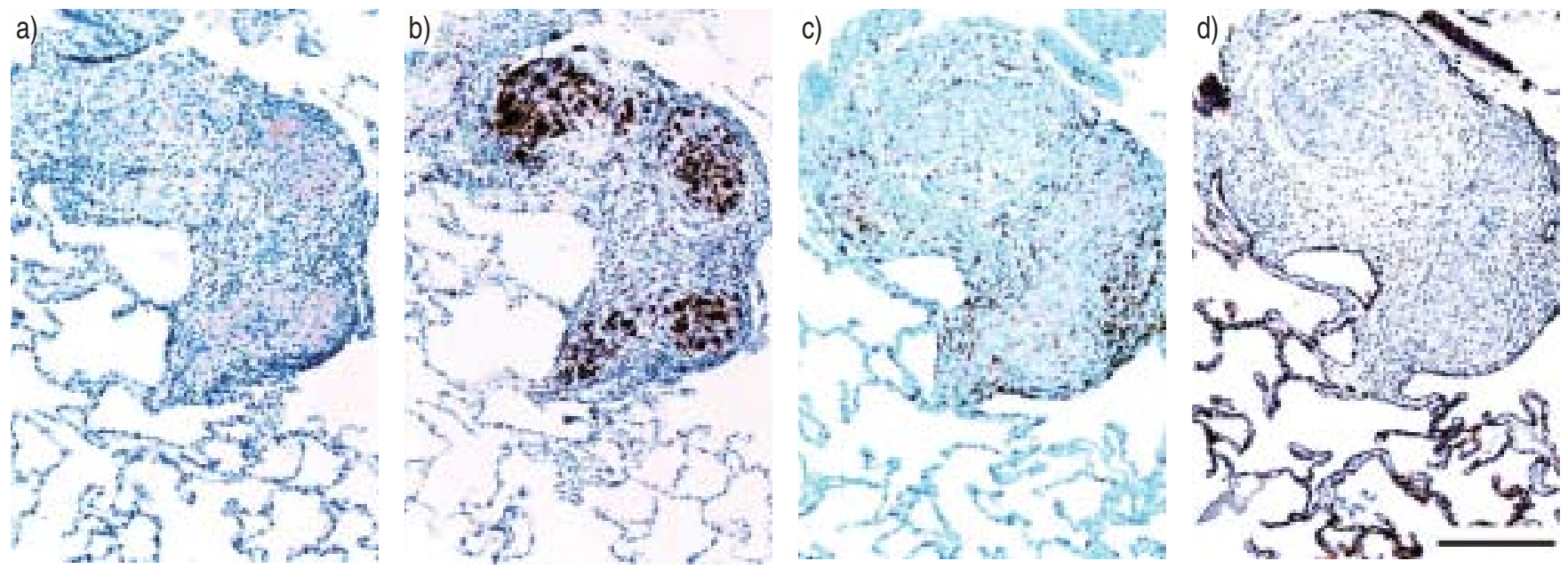

Fig. 2. - Indirect immunohistochemistry of serial sections from a) a tumour necrosis factor (TNF)- $\alpha$ from the lung of a sarcoidosis patient and b) CD68, c) CD3, and d) cytokeratin (MNF116) reveal that only CD68 colocalises with immunoreactivity for TNF- $\alpha$. Cells being immunoreactive for TNF- $\alpha$ are localised in the centre of granulomas where $\mathrm{CD} 68^{+}$macrophages are present. Epithelial cells are at the very periphery, whereas $\mathrm{CD}^{+}$lymphocytes are most frequent in the cortical zone of granulomas. Scale bar $=200 \mu \mathrm{m}$.

Multiple comparisons were performed according to Tukey's test or Dunn's method given that the null-hypothesis was rejected. A $\mathrm{p}=0.05$ was considered significant.

\section{Results}

Indirect IHC for TNF- $\alpha$ revealed a predominant presence of cells being immunoreactive for TNF- $\alpha$ within alveolar spaces (fig. 1) and also in the centre of noncaseating granulomas (fig. 2). By analysis of serial sections of transbronchial biopsies by indirect IHC for TNF- $\alpha, \mathrm{CD} 3, \mathrm{CD} 68$, and cytokeratins (MNF116), staining for TNF- $\alpha$ colocalised with CD68 immunoreactivity for macrophages only (figs 1 and 2) could be demonstrated. There was no correspondence in the staining patterns for TNF- $\alpha$ and CD3 or the epithelial marker MNF116, respectively. The CD3 immunoreactive cells were localised predominantly to a cortical zone of the granulomas and were only scattered widely among the cells of the granuloma centre, whereas MNF116 immunoreactive cells were

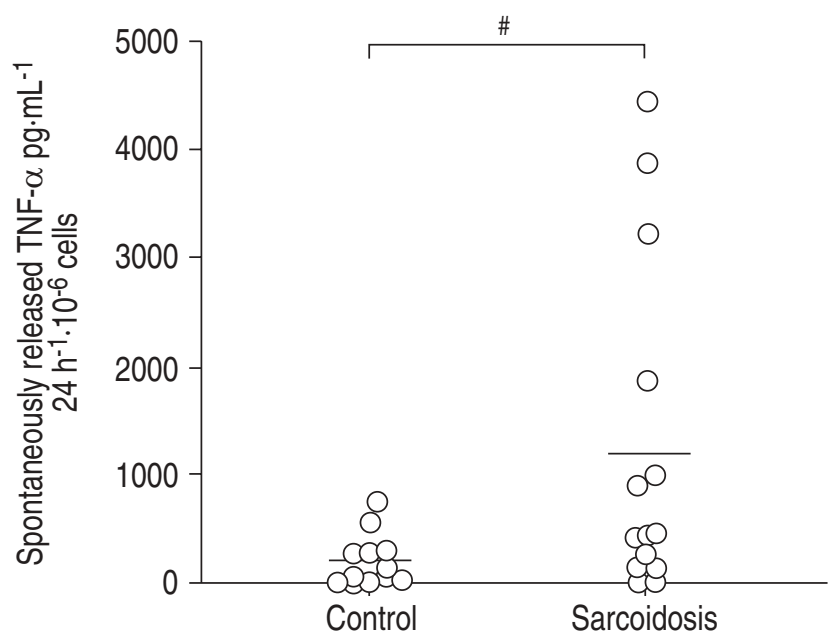

Fig. 3. - Levels of spontaneously released tumour necrosis factor (TNF)- $\alpha$ by cultured bronchoalveolar lavage cells as measured by enzyme-linked immunosorbent assay are significantly different in sarcoidosis patients versus the nonsarcoidosis control group. Means are indicated by the horizontal bars. ${ }^{\#}$ : $\mathrm{p}=0.029$. completely restricted to the circumference of granulomas (fig. 2).

The levels of sr-TNF- $\alpha$ from cultured BAL immune cells are shown in figure 3. In accordance to previous findings [19], patients with sarcoidosis exhibited significantly higher levels of TNF- $\alpha\left(1,226 \pm 404 \mathrm{pg} \cdot \mathrm{mL}^{-1}\right)$ than patients in the control group $\left(239 \pm 76 \mathrm{pg} \cdot \mathrm{mL}^{-1} ; \mathrm{p}=0.029\right)$. Notably, those cases that exhibited tissue immunoreactivity for $\mathrm{TNF}-\alpha$, as assessed by indirect IHC (fig. 4), were characterised by higher levels of spontaneously released TNF- $\alpha$ by cultured BAL immune cells $\left(1,667 \pm 504 \mathrm{pg} \cdot \mathrm{mL}^{-1}\right)$ compared with cases that were devoid of tissue immunoreactivity $\left(211 \pm 60 \mathrm{pg} \cdot \mathrm{mL}^{-1} ; \mathrm{p}=0.002\right)$. Accordingly, there were no significant differences in the levels of sr-TNF- $\alpha$ when comparing subgroups of cases with weak versus strong immunoreactivity for CD3 ( $\mathrm{p}=0.437)$, or with moderate versus strong immunoreactivity for MNF116 $(\mathrm{p}=0.308)$, respectively.

Although the differences in the levels of sr-TNF- $\alpha$ between

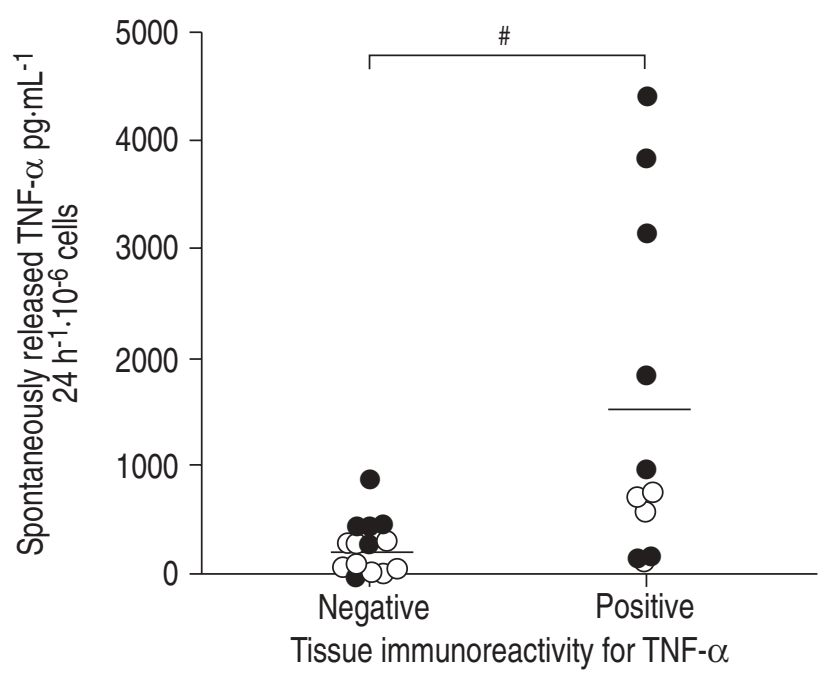

Fig. 4. - The group of patients exhibiting tissue immunoreactivity for tumour necrosis factor (TNF)- $\alpha$ are characterised by a significantly higher level of spontaneously released TNF- $\alpha$ than the group of patients without tissue immunoreactivity. Means are indicated by the horizontal bars. $\bigcirc$ : control; $\bullet$ : sarcoidosis patients. ${ }^{\#}$ : $p=0.002$. 


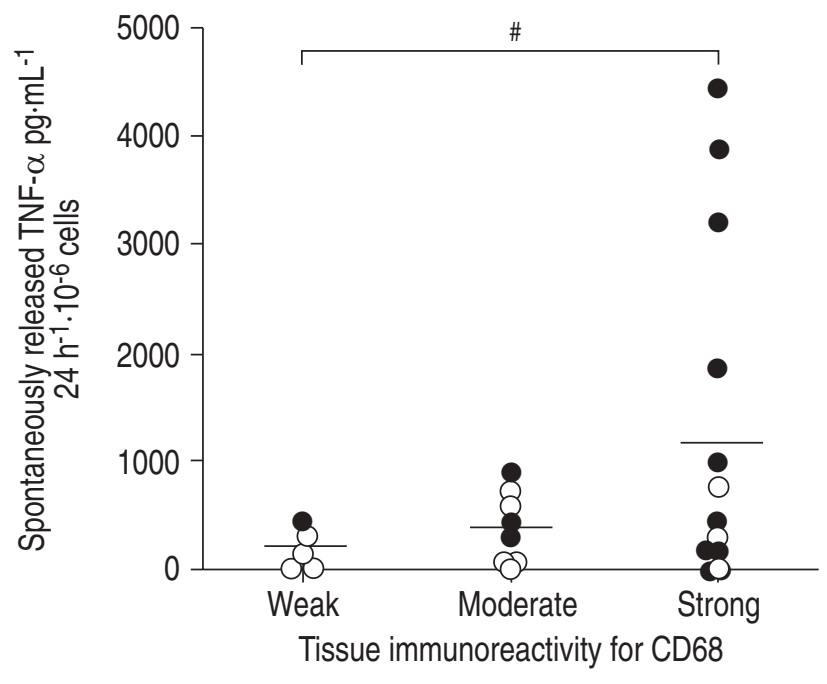

Fig. 5. - Patients grouped according to tissue immunoreactivity for CD68 exhibited no significant differences in the levels of spontaneously released tumour necrosis factor $(\mathrm{TNF})-\alpha$. $\bigcirc$ : control; $\bullet$ : sarcoidosis patients. Means are indicated by the horizontal bars. ${ }^{\#}$ : $\mathrm{p}=0.308$ using analysis of variance on ranks.

subgroups characterised by weak $\left(189 \pm 72 \mathrm{pg} \cdot \mathrm{mL}^{-1}\right)$, moderate $\left(374 \pm 118 \mathrm{pg} \cdot \mathrm{mL}^{-1}\right)$, or strong staining for CD68 $(1,242 \pm 439 \mathrm{pg}$. $\mathrm{mL}^{-1}$ ) did not reach statistical significance (fig. 5), there was a clear predominance of high levels of TNF- $\alpha$ in the subgroup of cases exhibiting strong immunoreactivity for CD68, i.e. with high density of CD68 immunoreactive cells.

To further characterise the subgroup of cases with high levels of sr-TNF- $\alpha$, the corresponding transbronchial biopsies were analysed for additional distinctive histological features. By means of this explorative approach, a subgroup of five patients could be identified that were characterised by the presence of aggregates of alveolar macrophages (fig. 6) rather than by well-developed granulomas. Notably, this subgroup comprised of the four patients with highest levels $\left(>1,500 \mathrm{pg} \cdot \mathrm{mL}^{-1}\right)$ of TNF- $\alpha$ (fig. 7). Kruskal-Wallis ANOVA on ranks indicates that this subgroup was significantly different in the level of sr-TNF- $\alpha\left(2,700 \pm 769 \mathrm{pg} \cdot \mathrm{mL}^{-1}\right)$ from the subgroup exhibiting normal histology $\left(221 \pm 61 \mathrm{pg} \cdot \mathrm{mL}^{-1} ; \mathrm{p}<0.05\right)$. The subgroup of patients characterised by the presence of granulomas exhibited an intermediate level of TNF- $\alpha$ of $460 \pm 137 \mathrm{pg} \cdot \mathrm{mL}^{-1}$.

To determine if the subgroup characterised by aggregates of alveolar macrophages exhibited distinctive clinical features, one-way ANOVA was performed (table 3). The BAL of this group of patients was characterised by fractions of alveolar macrophages, lymphocytes, and lymphocyte subpopulations that were mostly intermediate between cases with normal histology and patients with granuloma. However, these differences did not reach the level of significance. There was no correlation to the state of disease activity. Notably, however, patients characterised by the presence of aggregates of alveolar macrophages in their biopsies had the lowest vital capacities (78.9 $\pm 10.2 \%$ predicted), and total lung capacity $(73.8 \pm 10.4 \%$ pred) was significantly lower $(\mathrm{p}<0.05)$ in comparison with both other groups.
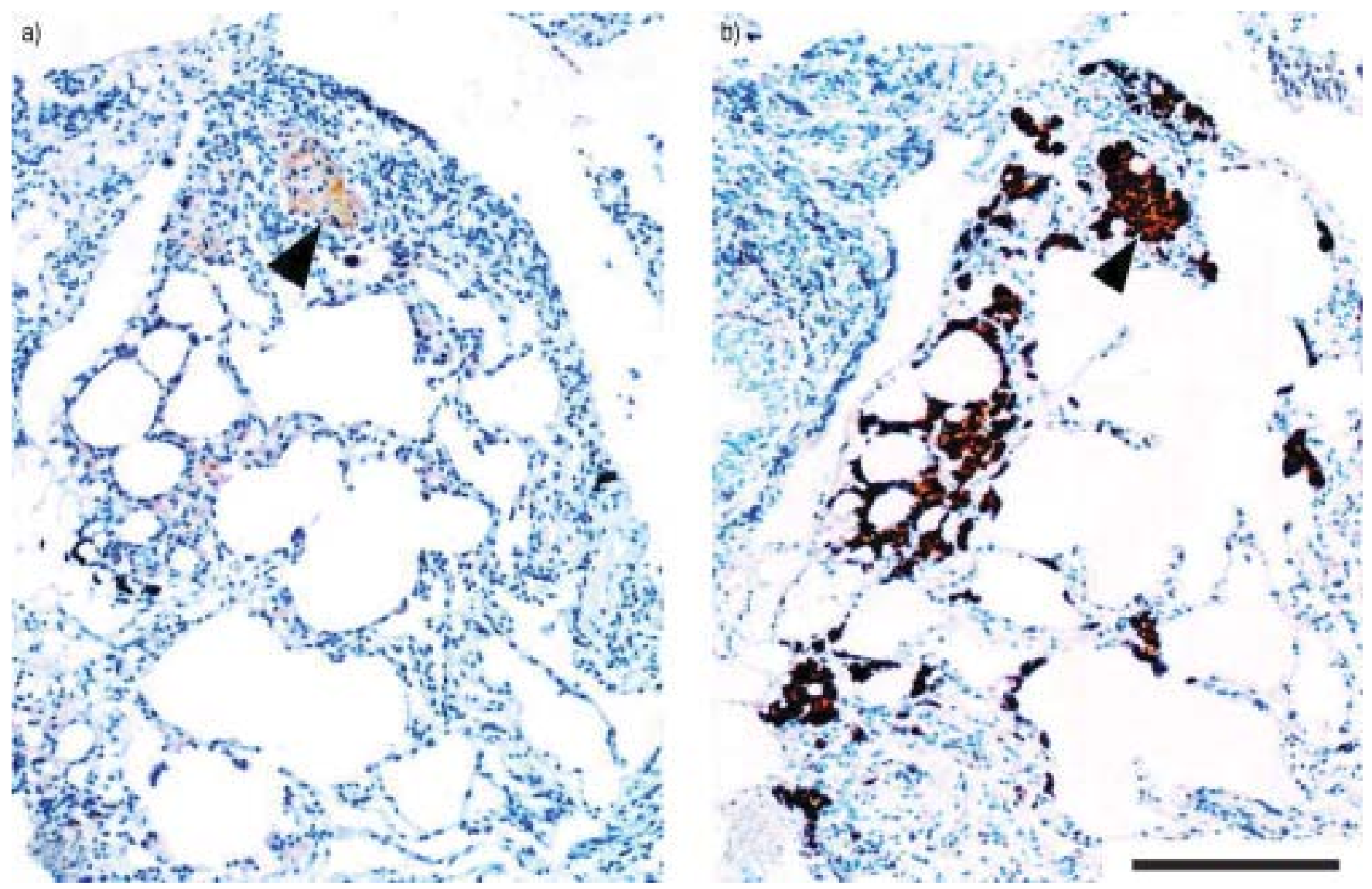

Fig. 6. - Indirect immunohistochemistry for a) tumour necrosis factor (TNF)- $\alpha$ from the lung of a sarcoidosis patient. The cultured bronchoalveolar lavage cells spontaneously released high levels of TNF- $\alpha\left(1,898 \mathrm{pg} \cdot \mathrm{mL}^{-1}\right)$. Adjacent serial section b) stained for CD68 reveals dense aggregates of alveolar macrophages (arrowheads) exibiting immunoreactivity for TNF- $\alpha$. Scale bar $=200 \mu \mathrm{m}$. 


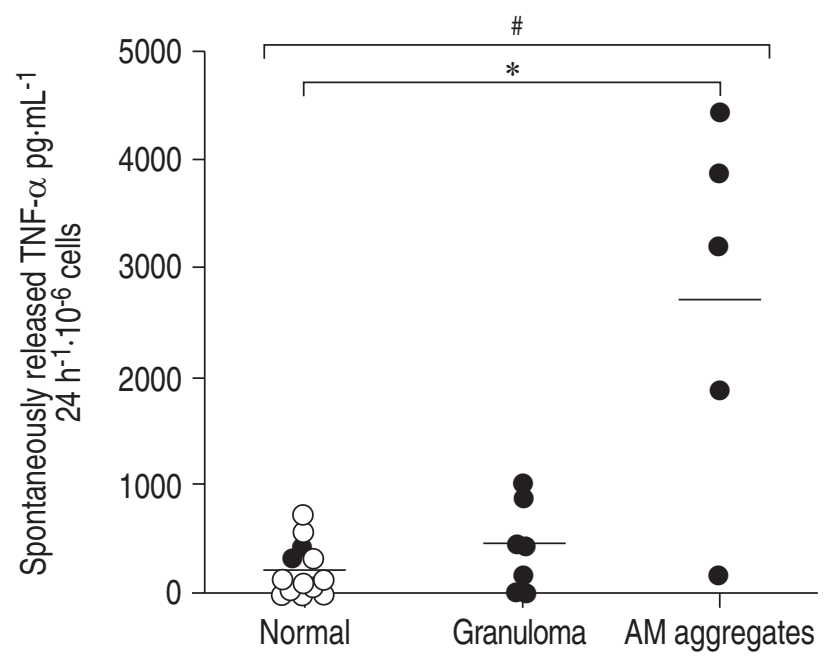

Fig. 7. - Patients grouped according to histological category. A subgroup of sarcoidosis patients characterised by the presence of aggregates of alveolar macrophages with immunoreactivity for tumour necrosis factor (TNF)- $\alpha$ exhibited the highest levels of spontaneously released TNF- $\alpha$. Means are indicated by the horizontal bars. $\bigcirc$ : control; 0: sarcoidosis patients. *: $\mathrm{p}<0.05$ using multiple comparison according to Dunn's method; ${ }^{\#}$ : $\mathrm{p}=0.013$ using analysis on variance on ranks.

\section{Discussion}

The hallmark of sarcoidosis is the formation of noncaseating granuloma, which is characterised by the accumulation, proliferation and spontaneous activity of macrophages and T-lymphocytes at sites of inflammation $[1,4,5]$. Among the mediators involved in granuloma formation, TNF- $\alpha$ is thought to play a major role $[2,6]$. In the present explorative study, alveolar macrophages were demonstrated to represent the most important cellular source for the release of TNF- $\alpha$ in situ during the pathogenesis of sarcoidosis. The highest levels of bioactive TNF- $\alpha$, spontaneously released by isolated BAL immune cells, were associated with the presence of aggregates of alveolar macrophages which therefore may represent predecessors to granulomas if not granulomas in statu nascendi. In a recent paper, the authors had previously demonstrated that increased TNF- $\alpha$ release segregates with an increased risk for progressing disease [19]. The present findings strongly corroborate the view for a major role of alveolar macrophages and TNF- $\alpha$ in the initial phase of the pathogenesis of sarcoidosis.

As comprehensively discussed by others [2, 5], the alveolar macrophage is a main player in the pathogenenesis of sarcoidosis. Cultured alveolar macrophages of sarcoidosis patients were shown to spontaneously release high levels of TNF- $\alpha[8,23,24]$ and IL-1 [9], which indicates that these cells are activated in vivo. These findings were supported by studies of the kinetics of TNF- $\alpha$ gene expression, which demonstrated that TNF- $\alpha$ messenger ribonucleic acid was maximally expressed immediately after retrieval of cells from the lung [8]. Furthermore, an autocrine mechanism was proposed by which alveolar macrophages regulate the pool of bioactive TNF- $\alpha$ by the release of soluble TNF receptors [18]. The finding of a strong association of tissue immunoreactivity for TNF- $\alpha$ in transbronchial biopsies with levels of bioactive TNF- $\alpha$ spontaneously released by BAL immune cells strongly supports the view that studies of BAL cells and fluid are indeed a reflection of the cellular milieu in which granulomas develop, as was emphasised recently [5]. Although the presence of TNF- $\alpha$ peptide and transcript in epithelioid and giant cells of sarcoid granulomas was shown previously [25], the present study's findings of intracellular immunoreactivity for TNF- $\alpha$ in aggregates of alveolar macrophages indicates that alveolar macrophages are likely to play an important role in the early phase of granuloma formation.

The higher levels of TNF- $\alpha$ production, observed in patients characterised by aggregates of alveolar macrophages when compared with patients with well-developed granulomas, further supports the notion that TNF- $\alpha$ is important during the initial phase of granuloma formation $[1,5]$. Recent data indicate that only a subpopulation of alveolar macrophages is responsible for the secretion of TNF- $\alpha$ in patients with pulmonary sarcoidosis [24]. Notably, in the present study,

Table 3. - Patient characteristics, grouped according to histological categories

\begin{tabular}{|c|c|c|c|}
\hline & Normal histology & Aggregates & Granuloma \\
\hline Subjects $n$ & $14^{\bullet}$ & 5 & 7 \\
\hline \multicolumn{4}{|c|}{ Disease activity (sarcoidosis only) } \\
\hline Active & 1 & 3 & 3 \\
\hline Inactive & 1 & 2 & 4 \\
\hline \multicolumn{4}{|l|}{ Cell differentials } \\
\hline Cell number $\times 10^{6} \cdot 10^{-2} \mathrm{~mL}$ & $10.1 \pm 8.8$ & $17.5 \pm 10.6$ & $12.3 \pm 6.8$ \\
\hline Alveolar macrophages \% & $91.2 \pm 9.1$ & $78.3 \pm 15.6$ & $66.0 \pm 15.2 *$ \\
\hline Lymphocytes $\%$ & $7.1 \pm 8.2$ & $18.7 \pm 15.3$ & $31.1 \pm 13.2 *$ \\
\hline \multicolumn{4}{|l|}{ Lymphocyte subpopulations } \\
\hline CD3 \% & $64.6 \pm 37.0$ & $79.2 \pm 9.3$ & $79.6 \pm 12.9$ \\
\hline CD4 \% & $41.8 \pm 18.6$ & $54.5 \pm 14.3$ & $51.0 \pm 13.9$ \\
\hline CD8 \% & $40.2 \pm 17.1$ & $23.7 \pm 7.1$ & $32.0 \pm 13.0$ \\
\hline $\mathrm{CD} 4 / \mathrm{CD} 8$ & $1.5 \pm 1.5$ & $2.6 \pm 1.2$ & $2.1 \pm 1.6$ \\
\hline IL-2R \% & $1.4 \pm 1.1$ & $1.8 \pm 1.6$ & $1.3 \pm 1.1$ \\
\hline ACE units & $43.8 \pm 19.6$ & $74.3 \pm 18.7$ & $93.5 \pm 38.8^{*}$ \\
\hline HLA-DR \% & $5.6 \pm 3.9$ & $10.6 \pm 2.2$ & $13.2 \pm 4.9^{*}$ \\
\hline \multicolumn{4}{|l|}{ Functional data } \\
\hline VC $\%$ pred & $100.6 \pm 21.9$ & $78.9 \pm 20.3$ & $93.2 \pm 23.4$ \\
\hline TLC $\%$ pred & $96.3 \pm 13.6$ & $73.8 \pm 20.7^{*, \#}$ & $99.9 \pm 6.5$ \\
\hline FEV1/VC $\%$ pred & $85.5 \pm 5.4$ & $83.3 \pm 15.9$ & $72.1 \pm 24.9$ \\
\hline$D \mathrm{~L}, \mathrm{CO} \%$ pred & $81.3 \pm 21.7$ & $71.7 \pm 27.3$ & $58.0 \pm 13.9$ \\
\hline
\end{tabular}

The data are presented as mean \pm SD unless otherwise stated; IL: interleukin; ACE: angiotensin-converting enzyme; HLA: human lymphocyte antigen; VC: vital capacity; TLC: total lung capacity; FEV1: forced expiratory volume in one second; DL,CO: diffusion capacity for carbon monoxide; ": inclusive of nonsarcoidosis. *: $\mathrm{p}<0.05$ versus normal group; ${ }^{\#}$ : $\mathrm{p}<0.05$ versus granuloma group. 
those patients characterised by this (explorative not diagnostic) histopathological feature, exhibited clinical parameters that were intermediate between patients with normal histology and with granulomas. This was with the exception of volume restriction, which was most prominent in patients with macrophage aggregates. Therefore, macrophage aggregates may represent at least predecessors to granulomas if not granulomas in statu nascendi.

Alveolar macrophages of patients with sarcoidosis exhibit multiple secretory cell functions in that they release other cytokines such as IL-15, growth factors, and chemokines such as monocyte chemotactic protein-1, RANTES (regulated, on activation, T-cell expressed and secreted) and macrophage inflammatory proteins- $1 \alpha$ and $-1 \beta[2,26,27]$. Thus, alveolar macrophages may strongly affect T-cell recruitment and T-cell response [28]. In turn, T-cells are also known to spontaneously release increased levels of some cytokines and chemokines, e.g. IL-2 and interferon- $\gamma$, in sarcoidosis [29-31]. The pattern of $\mathrm{T}$-cell cytokine production is indicative of sarcoidosis being a T-helper cell-1-mediated disease [12, 32]. Although no significant $\mathrm{T}$-cell immunoreactivity for $\mathrm{TNF}-\alpha$ was observed, a recent study reported that increased fractions of T-cells, which intracellularly expressed TNF- $\alpha$, were observed by fluorescence activated cell sorting (FACS) in BAL but not in peripheral blood of sarcoidosis patients compared with control subjects [11]. On the contrary, another study using FACS failed to detect any significant difference between sarcoidosis patients and healthy controls in the frequency of T-cells that intracellularly expressed TNF- $\alpha$ [13].

Alveolar epithelial cells are another potential cell type of the lung parenchyma that may contribute to the production of TNF- $\alpha$. MCRITCHIE et al. [17] demonstrated that lipopolysaccharide (LPS) can induce TNF- $\alpha$ production in primary cultures of alveolar epithelial type-II cells of the rat [17]. LPS-induced TNF- $\alpha$ production was shown to be primarily regulated at the transcriptional level, which is different from that of macrophages and neutrophils. Similarly, primary cultures of mouse bronchiolar-alveolar epithelial cells, consisting of both alveolar epithelial type-II cells and Clara cells, were shown by Northern analysis, ribonuclease protection assay, and immunocytochemistry to synthesise TNF- $\alpha$ [33]. In addition, immunoreactivity for TNF- $\alpha$ was reported for alveolar epithelial type-II cells of acute respiratory distress syndrome and idiopathic pulmonary fibrosis patients whereas no staining was observed in control tissues $[15,16,34]$. In the present study, there were no signs for any epithelial localisation of TNF- $\alpha$ neither in sarcoidosis nor in control patients.

From this study of transbronchial biopsies, the authors cannot definitely preclude that T-cells or epithelial cells produce low levels of tumour necrosis factor- $\alpha$ in sarcoidosis. However, the data indicates that alveolar macrophages are the main site of tumour necrosis factor- $\alpha$ production and the main source for the spontaneous release of this cytokine into the bronchoalveolar lavage in sarcoidosis patients.

Acknowledgements. The authors would like to thank the following for their technical assistance: I. Peterson and S. Langer (immunohistochemistry), H. Kühl (histology), S. Adam and D. Bubritzky (enzyme-linked immunoasorbent assay).

\section{References}

1. Newman LS, Rose CS, Maier LA. Sarcoidosis. $N$ Engl J Med 1997; 336: 1224-1234.

2. Müller-Quernheim J. Sarcoidosis: immunopathogenetic concepts and their clinical application. Eur Respir $J$ 1998; 12: 716738.

3. Costabel U, Hunninghake GW. ATS/ERS/WASOG statement on sarcoidosis. Sarcoidosis Statement Committee. American Thoracic Society. European Respiratory Society. World Association for Sarcoidosis and Other Granulomatous Disorders. Eur Respir J 1999; 14: 735-737.

4. Pabst R, Schuster M, Tschernig T. Lymphocyte dynamics in the pulmonary microenvironment: implications for the pathophysiology of pulmonary sarcoidosis. Sarcoidosis Vasc Diffuse Lung Dis 1999; 16: 197-202.

5. Conron M, Du Bois RM. Immunological mechanisms in sarcoidosis. Clin Exp Allergy 2001; 31: 543-554.

6. Kunkel SL, Chensue SW, Strieter RM, Lynch JP, Remick DG. Cellular and molecular aspects of granulomatous inflammation. Am J Respir Cell Mol Biol 1989; 1: 439-447.

7. Vassalli P. The pathophysiology of tumor necrosis factors Annu Rev Immunol 1992; 10: 411-452.

8. Müller-Quernheim J, Pfeifer S, Mannel D, Strausz J, Ferlinz R. Lung-restricted activation of the alveolar macrophage/monocyte system in pulmonary sarcoidosis. Am Rev Respir Dis 1992; 145: 187-192.

9. Hunninghake GW. Release of interleukin-1 by alveolar macrophages of patients with active pulmonary sarcoidosis. Am Rev Respir Dis 1984; 129: 569-572.

10. Müller-Quernheim J, Saltini C, Sondermeyer P, Crystal RG. Compartmentalized activation of the interleukin 2 gene by lung $\mathrm{T}$ lymphocytes in active pulmonary sarcoidosis. J Immunol 1986; 137: 3475-3483.

11. Prasse A, Georges CG, Biller H, et al. Th1 cytokine pattern in sarcoidosis is expressed by bronchoalveolar CD4+ and CD8+ T cells. Clin Exp Immunol 2000; 122: 241-248.

12. Mollers M, Aries SP, Dromann D, Mascher B, Braun J, Dalhoff K. Intracellular cytokine repertoire in different T cell subsets from patients with sarcoidosis. Thorax 2001; 56: 487-493

13. Wahlström J, Katchar K, Wigzell H, Olerup O, Eklund A, Grunewald J. Analysis of intracellular cytokines in CD4(+) and $\mathrm{CD} 8(+)$ lung and blood $\mathrm{T}$ cells in sarcoidosis. Am J Respir Crit Care Med 2001; 163: 115-121.

14. Zissel G, Ernst M, Rabe K, et al. Human alveolar epithelial cells type II are capable of regulating T-cell activity. J Investig Med 2000; 48: 66-75.

15. Nash JR, McLaughlin PJ, Butcher D, Corrin B. Expression of tumour necrosis factor-alpha in cryptogenic fibrosing alveolitis. Histopathology 1993; 22: 343-347.

16. Piguet PF, Ribaux C, Karpuz V, Grau GE, Kapanci Y. Expression and localization of tumor necrosis factor-alpha and its mRNA in idiopathic pulmonary fibrosis. Am J Pathol 1993; 143: 651-655.

17. McRitchie DI, Isowa N, Edelson JD, et al. Production of tumour necrosis factor alpha by primary cultured rat alveolar epithelial cells. Cytokine 2000; 12: 644-654.

18. Armstrong L, Foley NM, Millar AB. Inter-relationship between tumour necrosis factor-alpha $(\mathrm{TNF}-\alpha)$ and TNF soluble receptors in pulmonary sarcoidosis. Thorax 1999; 54: 524-530.

19. Ziegenhagen MW, Benner UK, Zissel G, et al. Sarcoidosis TNF-alpha release from alveolar macrophages and serum level of sIL-2R are prognostic markers. Am J Respir Crit Care Med 1997; 156: 1586-1592.

20. Fehrenbach H, Kasper M, Tschernig T, et al. Keratinocyte growth factor-induced hyperplasia of rat alveolar type II cells in vivo is resolved by differentiation into type I cells and by apoptosis. Eur Respir $J$ 1999; 14: 534-544.

21. Kasper M, Roehlecke C, Witt M, et al. Induction of apoptosis by glyoxal in human embryonic lung epithelial cell line L132. Am J Respir Cell Mol Biol 2000; 23: 485-491.

22. ATS, ERS, WASOG. Statement on sarcoidosis. Joint Statement of the American Thoracic Society (ATS), the European Respiratory Society (ERS) and the World Association of Sarcoidosis and Other Granulomatous Disorders (WASOG) 
adopted by the ATS Board of Directors and by the ERS Executive Committee, February 1999. Am J Respir Crit Care Med 1999; 160: 736-755.

23. Baughman RP, Strohofer SA, Buchsbaum J, Lower EE. Release of tumor necrosis factor by alveolar macrophages of patients with sarcoidosis. J Lab Clin Med 1990; 115: 36-42.

24. Pantelidis P, McGrath DS, Southcott AM, du Bois RM. Single-cell analysis: a novel approach to tumour necrosis factor-alpha synthesis and secretion in sarcoidosis. Eur Respir J 2002; 20: 1179-1184.

25. Myatt N, Coghill G, Morrison K, Jones D, Cree IA. Detection of tumour necrosis factor alpha in sarcoidosis and tuberculosis granulomas using in situ hybridisation. J Clin Pathol 1994; 47: 423-426.

26. Ziegenhagen MW, Schrum S, Zissel G, Zipfel PF, Schlaak M, Müller-Quernheim J. Increased expression of proinflammatory chemokines in bronchoalveolar lavage cells of patients with progressing idiopathic pulmonary fibrosis and sarcoidosis. J Investig Med 1998; 46: 223-231.

27. Capelli A, Di Stefano A, Lusuardi M, Gnemmi I, Donner CF. Increased macrophage inflammatory protein-1alpha and macrophage inflammatory protein-1beta levels in bronchoalveolar lavage fluid of patients affected by different stages of pulmonary sarcoidosis. Am J Respir Crit Care Med 2002; 165: $236-241$.
28. Agostini C, Facco M, Chilosi M, Semenzato G. Alveolar macrophage-T cell interactions during Th1-type sarcoid inflammation. Microsc Res Tech 2001; 53: 278-287.

29. Pinkston P, Bitterman PB, Crystal RG. Spontaneous release of interleukin-2 by lung $\mathrm{T}$ lymphocytes in active pulmonary sarcoidosis. N Engl J Med 1983; 308: 793-800.

30. Robinson BW, McLemore TL, Crystal RG. Gamma interferon is spontaneously released by alveolar macrophages and lung $\mathrm{T}$ lymphocytes in patients with pulmonary sarcoidosis. J Clin Invest 1985; 75: 1488-1495.

31. Hoshino T, Itoh K, Gouhara R, et al. Spontaneous production of various cytokines except IL-4 from CD4+ T cells in the affected organs of sarcoidosis patients. Clin Exp Immunol 1995; 102: 399-405.

32. Bäumer I, Zissel G, Schlaak M, Müller-Quernheim J. Th1/ Th2 cell distribution in pulmonary sarcoidosis. Am J Respir Cell Mol Biol 1997; 16: 171-177.

33. Warshamana GS, Corti M, Brody AR. TNF-alpha, PDGF, and TGF-beta(1) expression by primary mouse bronchiolaralveolar epithelial and mesenchymal cells: TNF-alpha induces TGF-beta(1). Exp Mol Pathol 2001; 71: 13-33.

34. Nash JR, McLaughlin PJ, Hoyle C, Roberts D. Immunolocalization of tumour necrosis factor alpha in lung tissue from patients dying with adult respiratory distress syndrome. Histopathology 1991; 19: 395-402. 